\title{
Developing Blended Learning Schoology To Enhance Scientific Communication Abilities For Digital Natives Generation
}

\author{
${ }^{1}$ Litasari Aldila Aribowo ,2 Bambang Subali , ${ }^{3}$ Sigit Saptono \\ $\left\{\underline{\text { litasarialdila@gmail.com }}{ }^{1}, \underline{\text { bambangfisika@mail.unnes.ac.id }}{ }^{2}\right.$, \\ sigit biounnes@mail.unnes.ac.id ${ }^{3}$ \} \\ ${ }^{1,2,3}$ Graduate School, Universitas Negeri Semarang, Indonesia
}

\begin{abstract}
Digital native generation is people who were born in digital era and having interaction with digital equipment in early childhood. The aim of this study is to embrace the scientific communication abilities through blended learning schoology. This study uses Research and Development (R\&D) approach with ADDIE model. Data collection techniques are carried out by observation and interview methods. The results of the observer's assessment through the scientific communication abilities of students who obtained an average score more than 60 increase from first to third meeting with each percentage $53 \%, 89 \%$, and $97 \%$. The scientific communication abilities of students as a Digital Native Generation in written aspect obtain an average score higher than the aspect of oral communication. Evidently, the existence of the natives digital generation have a negative impact that are the student's oral communication abilities become down because they are preoccupied with their gadgets, so that the student's socialization is reduced.
\end{abstract}

Keywords: Digital Natives, Blended Learning Schoology, Scientific Communication Abilities.

\section{Introduction}

Nowdays, human being's life is not far from using technology. People have been facilitated by the presence of the internet and developing technology. In this era, Students are belongs to the generation of digital natives which mean the generation who born when technology is in their environment. The digital native generation chooses to interact on social media as new spaces what they master. The existence of digital native generation has advantages and disadvantages. The advantage is that humans are able to keep up with the times and technology and it can facilitate human's work. However, there is a negative impact from the generation of digital natives, the ability to socialize with the other people is reduced because it has been preoccupied with existing technology, so that students' verbal communication skills become declining.

The fourth industrial revolution gives people the freedom to access information without constraints of space and time [1],[2],[3]. Education has an important role in the rapid development of technology, and technological development always has a positive and negative impact [4]. The integration of e-learning activities into the education system has become a necessity [5]. Evidently, in the implementation of e-learning in learning activities, 
there are still obstacles was found such as there is no interaction in the learning process. The teaching and learning process requires a system that can process in two directions through the presence of feedback in the learning process.

According to Asiyah [6] the use of e-learning will be better when collaborating with conventional learning. The use of gadget-based learning models can be used as a learning strategy to attract the attention of students [7]. Combining the learning model was often called Blended Learning. Blended learning is learning that combines web based learning with face to face learning [8]. The learning process is a process of communication between educators and students, or between students. Learning techniques in college or universities that often occur was doing presentations conducted by students. In presentation techniques only develop students 'communication skills verbally, so that other supporting activities are needed that can improve students' written communication skills. The Efforts to improve students' written communication skills can be done by giving assignments to analyze, convey ideas and compile the results of discussions in written and systematic. This study aimed to identify the scientific communication ability of the digital natives generation through blended learning schoology.

The blended learning schoology model was doing lecturing with online-offline-online designed which has the advantages to overcome the limitations of time, structured and transparent of task and value management, flexible online learning and being able to identify oral and written scientific communication skills. Scientific communication according to Samatowa as quoted by Nurhayati [9] is a skill to communicate scientific knowledge from the findings and studies for various purposes to various target groups. Indicator of scientific communication skills as presented by Levy [10] include information retrieval, scientific writing, listening and observing, information representation, and knowledge presentation. Indicators of communication skills are divided into two types, they were oral and written communication. The first, third and fifth indicators are oral communication while the second and fourth indicators are written communication. Students who have the above characteristics in the learning process, it can be said that these students have strong communication skills. Students who have communication skills will have good results in learning because these students are active in learning activities, can write data systematically and express ideas. Scientific communication is important to be developed especially in Pre-service teachers. This is reinforced by the opinion of Jeon [11] that scientific communication not only plays an important role in developing science for civilization but also needed to increase citizens in the future.

\section{Method}

This type of research was Research and Development ( R \& D). This study was designed using the ADDIE model (Analysis, Design, Development, Implementation, and Evaluation) adopted from Dick \& Cary [12]. The activities that was carried out in the analysis step was analyzing student's needs, analyzing the potential availability of learning materials and analyzing student's value documents. The analysis was intended to collect preliminary data needed for the development of learning models. The design was done by designing the blended learning schoology model. The development steps included the development of anatomy classes and physiology of organism in schoology, made instruments to measure product validity, revising products according to expert validation suggestions for improving 
the appearance of product and material products. The implementation step included product testing on a small scale and large scale. The data on students' scientific communication skills towards Blended Learning Schoology was measured through the results of classroom observations and observation of student assignments according to indicators of scientific communication skills. Interview activities were also conducted to strengthen the results of the observer's assessment. The score of the assessment results was arranged in the tabulation of data, then calculated by the percentage of all aspects with the Sudijono formula [13] as follows :

Explanation :

$$
P=\frac{f}{N} \mathrm{x} 100 \%
$$

$\mathrm{P}=$ percentage (completeness of student learning outcomes classically)

$\mathrm{f}=$ number of scores obtained (number of students completed)

$\mathrm{N}=$ maximum number of scores (total number of students)

The percentage of achievement of scientific communication skills of students obtained from the adoption of Aziza [14] can be categorized according to Table 1 :

Table 1. Criteria for Assessing the Capability of Scientific Communication

\begin{tabular}{cc}
\hline Percentage $(\%)$ & Criteria \\
\hline $\mathrm{x}>80$ & Very high \\
$60<\mathrm{x} \leq 80$ & High \\
$40<\mathrm{x} \leq 60$ & Fair \\
$20<\mathrm{x} \leq 40$ & Poor \\
$\mathrm{x} \leq 20$ & Very poor \\
\hline
\end{tabular}

The results of the study of the blended learning schoology model was effective towards the student's scientific communication skills in the anatomy and physiology of organism if the score gain of the students reach $>80 \%$ students with the minimum "high" category.

\section{Results and Discussion}

The blended learning schoology model can be used to identify students' scientific communication skills both in online and face-to-face learning. The BLS model was effective in enhancing students' scientific communication skills if $80 \%$ of students in the third meeting score in a high category. Assessment of student scientific communication skills was obtained from the results of the assessment of the observation sheet. In face-to-face learning there were 3 indicators of assessment of students' scientific communication skills that carried out verbally, they were information retrieval, listening and observing and knowledge presentation. Oral scientific communication was an integral part of scientists who can communicate and engage with peers and wider non-scientific audiences [15]. Scientific communication indicators assessed from the results of written communication were indicators of scientific writing and information representation. The results of the observations of scientific communication skills can be seen in Figure 1 


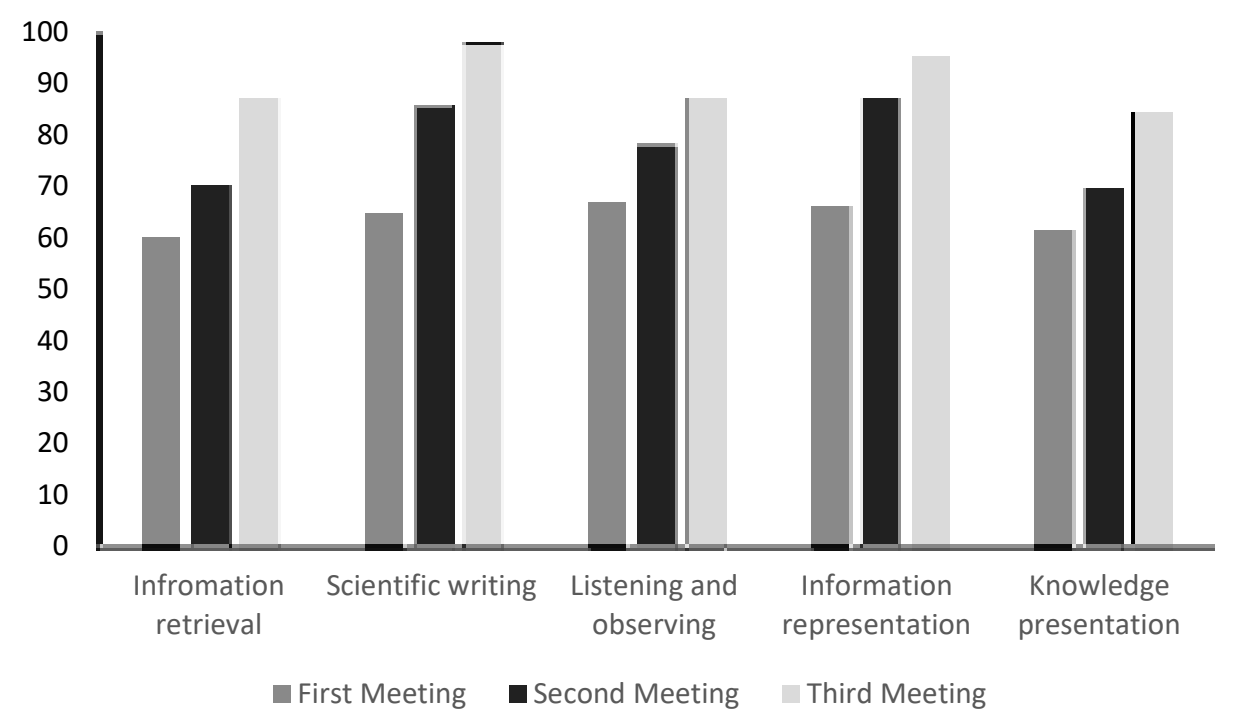

Figure 1. Average Score of Scientific Communication Ability

Based on figure 1, the indicator of scientific writing and information representations have a higher average than the other 3 indicators. Both indicators are indicators of scientific communication in writing. Students tend to have written communication skills better than oral communication. The written communication that carried out in this study was through the activity of making material resumes and mind mapping. The existence of written communication skills gives an opportunity for students to convey their ideas in writing. Based on the results of interviews with several students, written communication is very useful for students who have weaknesses in conveying ideas verbally because of lack of confidence. It is related with the opinion of Ulpa [16] that students who have knowledge skills but are difficult in speaking ability so that written ability will be easier. Based on the results of observations, face-to-face activities was aimed to knowing students' oral communication ability were only dominated by members of certain groups. It can caused some other group members who lack confidence to be passive and did not explore their verbal communication ability maximumly.

Blended learning is perceived as useful, enjoyable, supportive, flexible and motivator for learners [17]. The Blended learning schoology model was effective for identifying students' scientific communication skills if the average results of the observer's assessment have exceeded $80 \%$ or included in the high category. The percentage of students who obtain the total score of scientific communication skills according to 5 criteria can be seen in table 2 : 
Table 2. Percentage of Learners by Total score of Communication Skills

\begin{tabular}{lccc}
\hline \multirow{2}{*}{ Category } & \multicolumn{3}{c}{ Student's Percentage of the meeting } \\
\cline { 2 - 4 } & 1 & 2 & 3 \\
\hline Very high & 6 & 25 & 86 \\
High & 47 & 64 & 11 \\
Fair & 39 & 8 & 3 \\
Low & 8 & 3 & 0 \\
Very low & 0 & 0 & 0 \\
\hline
\end{tabular}

From table 2 the percentage of students who obtained a score of scientific communication skills with a high category from the first to the third meeting was increased. At the first meeting, the number of students in the very high and high categories was $53 \%$, while the second meeting was $89 \%$ and the third meeting was $97 \%$. The effectiveness of the blended learning schoology model was obtained from the percentage of observers' assessment of scientific communication skills at the third meeting. These results stated that the blended learning schoology model in anatomy courses and physiology was effective to enhance students' scientific communication ability because the result of scores gain reach $>80 \%$ students with a high minimum category.

\section{Conclusion}

Blended learning schoology was effective to use to improve students' scientific communication skills which the results of the average score from the aspects of information retrieval, scientific writing, listening and observing, information representation and knowledge presentation was increasing from each meeting. Aspects of scientific writing and information representation which are the aspects of scientific communication ability in writing obtain higher average scores than aspects of oral scientific communication.

Acknowledments. The author expresses her gratitude the Hibah Penelitian Tesis Pascasarjana Universitas Negeri Semarang for providing research funding. 


\section{Reference}

[1] Buer, S. V., Strandhagen, J. O., and Chan, F. T. S.: The link between Industry 4.0 and lean manufacturing: mapping current research and establishing a research agenda. International Journal of Production Research. Vol 56, pp. 2924-2940 (2018).

[2] Morrar, R., Arman, H., and Mousa, S.: The Fourth Industrial Revolution (Industry 4.0): A Social Innovation Perspective. Technology Innovation Management Review. Vol 7, pp. 12-20 (2017).

[3] Thai, H. Van, Thi, L., and Anh, K.: The 4.0 Industrial Revolution Affecting Higher Education Organizations' Operation in Vietnam. International Journal of Management Technology. pp. 112 (2017).

[4] Husaini, M.: Pemanfaatan Teknologi Informasi dalam Audit Investigatif. Jurnal Mikrotik. pp. 141-147 (2014)

[5] Bicen, H., Ozdamli, F., and Uzunboylu, H.: Online and blended learning approach on instructional multimedia development courses in teacher education. Interactive Learning Environments vol. 22, pp. 529-548 (2014).

[6] Asiyah, S., Budiyanto, C. W., and Tamrin, A. G.: Technology Acceptance Model in the Analysis of the Influence Of E-Learning Implementation to Students' Motivation. IJIE (Indonesian Journal of Informatics Education) vol. 2, pp. 147-152 (2018).

[7] Aribowo, L. A., Saptono, S., Subali, B and Marwoto, P.: The Use Of Gadget For Science Students Of Semarang State University In The Millenial Era. Scientiae Educatia: Jurnal Pendidikan Sains. Vol. 8, pp. 1-12 (2019).

[8] Kerres, M., and Witt, C. D.: A Didactical Framework for the Design of Blended Learning Arrangements. Journal of Educational Media vol. 28, pp: 101-113 (2003).

[9] Nurhayati, Widya, Sutji W dan Isa A.: Peningkatan Komunikasi Ilmiah Pembelajaran IPA Melalui Model Kooperatif Tipe Think Talk Write. Joyful Learning Journal , vol 1, pp. 12-25 (2012).

[10] Levy, O.S, Eylon. B, and Scherz.Z.: Teaching Communication Skills in Science: Tracing teacher Change. Israel: The Department of Science Teaching, The Weizmann Institute of Science, Rechovot, vol 24, pp. 462-477 (2008).

[11] Jeon, S., and Park, J.: Analysis on communication skills in science education. Advanced Science and Technology Letters, vol. 36, pp. 18-21 (2013).

[12] Dick and Carey.: The Sistematic Design of Instruction Fourth Edition: Harper Collins College Publisher (1996)

[13] Sudijono, A.: Pengantar Statistik Pendidikan. Jakarta: Rajawali Pers (2009).

[14] Aziza, E. N and Liliawati, W.: Profile Of The Scientific Communication Skill Of Madrasah Aliyah Students (Islamic Senior High School) On The Topic Of Elasticity. International Conference on Education and Science (ICONS), pp. 1269-1274 (2017).

[15] Mercer-Mapstone, L. D., and Matthews, K. E.: Student perceptions of communication skills in undergraduate science at an Australian research-intensive university. Assessment \& Evaluation in Higher Education, vol 42, pp. 98-114 (2017).

[16] Ulpa, M., Abdurrahman, A., and Wahyudi, I.: Perbandingan Hasil Belajar Fisika Ditinjau Dari Kemampuan Argumentasi Oral Dan Tertulis. Jurnal Pembelajaran Fisika, vol 2, pp. 1-13 (2014).

[17] Güzer, B., \& Caner, H.: The past, present and future of blended learning: an in depth analysis of literature. Procedia-social and behavioral sciences. vol 116, pp. 4596-4603 (2014). 